\title{
SCHOOL ADMINISTRATORS' AND TEACHERS' VIEWS ABOUT THE USE OF SOCIAL MEDIA AT SCHOOLS AS A NEW PLATFORM IN ORGANIZATIONAL COMMUNICATION
}

\author{
Emine Doğan ${ }^{1 i}$, \\ Mehmet Sabir Çevik ${ }^{2}$ \\ ${ }^{1}$ Çiğli Primary School, Teacher, Dr., \\ Kahramanmaraş, Turkey \\ ${ }^{2}$ Yunus Emre Primary School, \\ School Deputy Principal, Dr., \\ Siirt, Turkey
}

\begin{abstract}
:
This research aimed to evaluate the school administrators' and teachers' views about the use of social media at schools as a new platform in organizational communication. Phenomenology, a qualitative research model, was used in the research. A total of 17 participants who were included in the research (school administrators and teachers) were selected by using the purposive sampling methods that were well-suited to the qualitative research studies, namely, the "maximum variation sampling method" and the "criterion sampling method". Participants' views were received via semi-structured and in-depth interviews. The research data were analyzed by using the NVivo 12.0 software. The inductive descriptive analysis, content analysis, and the constant comparison technique were utilized in the interpretation of interview texts. In this context, the participants' views were grouped under the themes of "views about the definition of social media", "views about whether the use of social media at schools is necessary", "views about the purpose of using social media at schools", "views about the likely effects of using social media at schools", and "views about recommending the use of social media at schools". In the research, the participants stated that they viewed social media as a communication tool, the use of social media at schools was necessary, social media platforms could be used for education \& instruction and giving (sharing) information, social media could have positive effects besides negative effects, and certain societal, technical, and legal measures should be taken to assure that the social media was used effectively. To ensure the professional use of social media at schools, it is recommended that educators undergo professional development.
\end{abstract}

Keywords: social media at schools, social media, school administrators, and teacher

${ }^{\mathrm{i}}$ Correspondence: email dgnemn@gmail.com 


\section{Introduction}

"Digital 2020: Global Digital Overview", the report presenting the technology usage statistics for the world population, indicates that approximately 4.54 billion people in the world were internet users and more than 3.8 billion of these internet users were also social media users (Houtside \& WeAreSocial, 2020). The data released by the Turkish Statistical Institute (TUIK, 2019) show that the percentage of information technology use by households reached 79\%. TUIK 2019 report also revealed that internet users used the internet mostly to acquire information from websites of public institutions and communicate via social media. Along with the spread of the internet and the increase in its use, the manners in which organizations communicated, acquired information, and did business began to change (Tayfun, 2010).

In organizational communication, there are two types of communication channels, that is, formal communication and informal communication. For Banuta (2011), while formal communication is inadequate to satisfy organization employees' needs and does not generate a sense of belonging, informal communication offers the opportunity to have a more interactive and dynamic process. The social media that is depicted as the informal communication type in organizations refers to internet communication platforms such as Twitter, Facebook, Instagram, and blogs where users are in contact with other users, can clearly provide the list of users with whom they are in contact, can allow other users to view their contacts listed in the system, and can express themselves (Akgemci, Ada, \& Korkmaz, 2016). Social media is of importance as it promotes the exchange of words, images, videos, and audio records, reduces the burden on formal communication, develops the team spirit among members of the organization, enhances the effectiveness of teamwork, enables participation, and promotes accessibility through conversations, mobile applications, and smartphones (Karcıoğlu, Timuroğlu, \& Çınar, 2009). Therefore, organizations or institutions show a great interest in social media platforms that can reflect their identities (Güçlü \& Özdoğru, 2018).

The organizations communicate with their target groups to attain their general and private objectives. Communication efforts undertaken by administrations of organizations are called organizational communication (Tosun, 2003). In organizational communication, social media platforms became a communication instrument connecting all stakeholders interested in activities in the organization (Northeastern University, 2007). At the same time, the developments in organizational communication technologies closely affected educational organizations and were effective in enhancing the use of social media in educational organizations (Balc1 \& Şahin, 2016).

The use of social media in educational settings was demanded considerably by educators (Mazer, Murphy, \& Simonds, 2007). In the study by Cox and McLeod (2014), the use of social media platforms in education is viewed as a method which can eliminate time and space constraints and in which any content can be regularly shared with stakeholders. The research studies indicate that the social media platforms were mostly for education and instruction purposes (Menteşe, 2013; Selwyn, 2007; Uyanık-Aktulun ve 
Elmas, 2019). Moreover, it is discerned that the research studies about the use of social media in education focused on different aspects of the use of social media such as information management (Richardson 2009), the establishment of effective communication with partners (Faizi, Afia, \& Chiheb, 2013), the interaction between teacher and student (Şad \& Demir, 2019), cyberbullying and victimization (Baran, Keskin, \& Genç, 2014), continuation of professional development (Fancera, 2019), social media and addiction (Çam \& İşbulan, 2012), attention deficit and failure to focus on lessons (Kulesza, DeHondt, \& Nezlek, 2011), students' and teachers' problem behaviors in the use of social media (Morahan-Martin \& Schumacher, 2000). According to Huffman (2013), the greatest benefit of using social media in education is the ease, convenience, and speed of accessing and disseminating information. In other words, social media provides individuals with the opportunity to get information instantaneously. However, the use of social media in education also brings about certain discussions. Some researchers asserted that, despite its benefits, social media would prevent students from using their conventional learning skills and even eliminate teachers' and students' conventional roles (Brabazon, 2007). The study by Sugimoto, Hank, Bowman, and Pomerantz (2015) puts forward that social media was likely to blur students' formal relationships and boundaries anticipated to be maintained with teachers. Therefore, it is discerned that it was likely to be faced with different problems and circumstances associated with being in communication with the school via social media.

The use of social media platforms by internet users more frequently (TÜIK, 2019) induced educators to share posts through social media. The research studies about the use of social media at schools focused on the school objectives of creating social capital with stakeholders (Young, Berube, \& Perry, 2008), sharing ethical responsibilities (Keeney, 2019), providing accurate information quickly in times of crisis besides promoting transparency perception in such situations (Aharoney, 2012), gathering information on the environs of the school, strengthening institutional identity, and developing relations with the environment (Newland-Hill \& White, 2000), building confidence and discussing topics such as reforms, school problems, and young individuals' risky behaviors (Carr, 2007), and disseminating announcements, news, and updates about the school (Larkin, 2011). The study by Olmstead (2013) identified that $91 \%$ of the parents demanded to be informed about school activities via social media, and the most important reason for this demand was the possibility of becoming friends with other parents and reaching the school administrator more frequently and quickly. Besides, in the relevant literature, there are also findings asserting that the use of social media had a variety of advantages and disadvantages for schools. The study by Cox and McLeod (2013) stated that the use of social media by school administrators contributed to the professional development of school administrators, developed a positive image for the school, and enhanced the resourcing support along with the establishment of strong ties with stakeholders, and also, the study by Dembo (2015) found that the social media could help school principals' efforts to create a positive school culture and take their plans further. Likewise, the study by Carr (2011) puts forward that the school authorities 
needed to inform their stakeholders about positive developments taking place at the school, and hence, the negative news and rumors could be avoided, and also, by establishing an open and honest communication via social media, the confidencebuilding could be achieved. In the study by Newbury, Humphreys, and Fuess (2014) referring to the harmful effects of social media, it was asserted that social media had the "uncontrollability" risk and this form of communication taking place at a large scale took a very long time. Thus, the study by Yildiz Durak (2019) emphasized that educators should have the necessary awareness, skills, and cognitive capabilities in relation to the use of social media. In this direction, educators should pay attention to what they post on social media, respect the privacy of students and school employees, and avoid sharing inappropriate posts likely to be disclosed in media in a negative context (Carr, 2011). Certain measures against the negative effects of social media are taken also at schools in Turkey. The procedures and principles about the use of social media in the school context were designated by the Ministry of National Education of Turkey (MNET). Through a circular, the MNET bans "uploading any type of audio, image, and video, which are likely to have negative effects on an individual's psychological and social situation, to the general network platforms" and hence, educators are warned about the social media content to be posted (MNET, 2017).

The use of social media by schools in institutional communication is a new phenomenon. The manner in which schools use social media becomes embedded as a part of the school culture. Even if the use of social media by schools offers a variety of advantages, it also paves the way for certain problems. Teachers and school administrators who use social media are responsible for making positive contributions and reducing and solving the problems likely to influence all stakeholders and the school. Considering the role to be played by administrators and teachers for the proper use of social media at the school, it is discerned that administrators' and teachers' views about how social media affects the relationship between stakeholders and the school are important. The presence of a limited number of studies about the use of social media accounts at educational organizations in Turkey (Ekici \& K1yıc1, 2012; Feyzioğlu, 2016; Köse, 2018; Şahin, 2017; Şahin \& Üstüner, 2018) and also the recommendation presented in the relevant literature about the need to analyze activities performed by schools via social media (Cox \& McLeod, 2013; Güçlü \& Özdoğru, 2018) laid the groundwork for the current research.

It can be asserted that, in the relevant literature, there was a gap about how the schools in Turkey adopted social media platforms as a part of the communication, why these schools included social media platforms in the communication, and what effects the social media platforms had on schools. The presence of a very limited number of studies about this topic in the relevant literature in Turkey (Ekici \& K1y1c1, 2012; Feyzioğlu, 2016; Köse, 2018; Şahin, 2017; Şahin \& Üstüner, 2018) shows that there were uncertainties as well as the lack of knowledge about the use of social media at schools in Turkey. Thus, by exploring the process of using social media at schools, the current research will provide educators with useful information and reveal how social media 
affects relations with stakeholders. Moreover, it is considered that the research will enable schools to more accurately, effectively, and efficiently use social media that has a considerably wide sphere of influence, and also, the research will raise policy makers' awareness about the necessity of giving support for the use of social media by schools. Lastly, it can be said that addressing the phenomenon of social media at schools from a broad, detailed, and holistic perspective is another important aspect of the research.

\subsection{Research Aim}

This research aimed to evaluate the school administrators' and teachers' views about the use of social media at schools as a new platform in organizational communication. In light of this basic aim, this research tried to seek answers to the questions below:

1) What do the participants think about the meaning of social media?

2) What do the participants think about whether the use of social media at schools is necessary?

3) What do the participants think about the purpose of using social media at schools?

4) What do the participants think about the likely effects of using social media at schools?

5) What do the participants think about the effective and efficient use of social media at schools?

\section{Method}

\subsection{Research Model}

This research was conducted with qualitative research methods to deeply analyze the use of social media at schools. As the research aimed to evaluate the participants' individual experiences and views about the use of social media at schools, it was conducted as per a qualitative research design, phenomenology, which was well-suited to the nature of the research aim. Phenomenology is to analyze a phenomenon from a holistic perspective in accordance with the nature and meaning of daily experiences (Creswell, 2020; Langridge, 2007; Patton, 2014). In this context, this research tried to identify the phenomenon of "social media at schools" as its topic on the basis of school administrators' and teachers' experiences.

\subsection{Study Group}

In the research, the study group was composed of 17 participants serving at schools that had a variety of social media accounts in Kahramanmaraş and Siirt provinces of Turkey in the fall semester of the academic year of 2021-2022. The "maximum variation sampling method" and the "criterion sampling method", the purposive sampling methods that were well-suited to qualitative research studies, were used for the sample selection in the research. In the maximum variation sampling method, the individuals to be included in the research are selected to have the attributes necessary to ensure enough diversity relevant to the research topic (Yıldırım \& Şimşek, 2013), and in the criterion sampling 
method, the individuals to be included in the research are selected as per a series of certain criteria (Marshall \& Rossman, 2014). In the research, the maximum variation sampling method was utilized to reveal diverse aspects of the research phenomenon, and the criterion sampling method was employed to assure that the participants would make a detailed evaluation of the social phenomenon at schools. In this context, attention was paid to ensure that the participants had diversity in terms of gender, marital status, position, school level, education level, age, duration of service at the school, and the province where they served, and also, it was assured that the participants were working at least for one year at the school where they served during the research. It is presumed that the participants who were working at least for one year at the school during the research would have enough professional experience to make inferences about the use of social media at the school. Table 1 displayed the demographic data about research participants.

Table 1: Demographic data about research participants

\begin{tabular}{|c|c|c|c|c|c|c|c|c|}
\hline Participant $^{*}$ & Gender & $\begin{array}{c}\text { Marital } \\
\text { status }\end{array}$ & Position & $\begin{array}{c}\text { School } \\
\text { level }\end{array}$ & $\begin{array}{c}\text { Education } \\
\text { level }\end{array}$ & Age & $\begin{array}{c}\text { Duration of } \\
\text { service at } \\
\text { the school }\end{array}$ & Province \\
\hline $\mathrm{T} 1$ & Male & Married & Teacher & $\begin{array}{l}\text { Middle } \\
\text { school }\end{array}$ & $\begin{array}{c}\text { Bachelor's } \\
\text { degree }\end{array}$ & 34 & 4 & Kahramanmaraş \\
\hline $\mathrm{T} 2$ & Male & Single & Teacher & $\begin{array}{c}\text { Elementary } \\
\text { school }\end{array}$ & $\begin{array}{c}\text { Bachelor's } \\
\text { degree }\end{array}$ & 30 & 3 & Kahramanmaraş \\
\hline T3 & Male & Married & Teacher & $\begin{array}{c}\text { High } \\
\text { school }\end{array}$ & $\begin{array}{c}\text { Bachelor's } \\
\text { degree }\end{array}$ & 44 & 10 & Siirt \\
\hline $\mathrm{T} 4$ & Male & Married & Teacher & $\begin{array}{c}\text { High } \\
\text { school }\end{array}$ & $\begin{array}{c}\text { Bachelor's } \\
\text { degree }\end{array}$ & 38 & 7 & Siirt \\
\hline $\mathrm{T} 5$ & Male & Married & Teacher & $\begin{array}{c}\text { Elementary } \\
\text { school }\end{array}$ & $\begin{array}{c}\text { Bachelor's } \\
\text { degree }\end{array}$ & 39 & 12 & Siirt \\
\hline T6 & Male & Married & Teacher & $\begin{array}{c}\text { High } \\
\text { school }\end{array}$ & $\begin{array}{c}\text { Bachelor's } \\
\text { degree }\end{array}$ & 51 & 9 & Siirt \\
\hline $\mathrm{T} 7$ & Female & Married & Teacher & $\begin{array}{c}\text { Middle } \\
\text { school }\end{array}$ & $\begin{array}{l}\text { Master's } \\
\text { degree }\end{array}$ & 45 & 8 & Kahramanmaraş \\
\hline DP1 & Male & Married & $\begin{array}{c}\text { Deputy } \\
\text { Principal }\end{array}$ & $\begin{array}{c}\text { Middle } \\
\text { school }\end{array}$ & $\begin{array}{c}\text { Master's } \\
\text { degree }\end{array}$ & 34 & 3 & Kahramanmaraş \\
\hline DP2 & Male & Married & $\begin{array}{c}\text { Deputy } \\
\text { Principal }\end{array}$ & $\begin{array}{c}\text { Elementary } \\
\text { school }\end{array}$ & $\begin{array}{c}\text { Bachelor's } \\
\text { degree }\end{array}$ & 37 & 4 & Siirt \\
\hline DP3 & Male & Married & $\begin{array}{c}\text { Deputy } \\
\text { Principal }\end{array}$ & $\begin{array}{c}\text { Middle } \\
\text { school }\end{array}$ & $\begin{array}{c}\text { Bachelor's } \\
\text { degree }\end{array}$ & 34 & 2 & Kahramanmaraş \\
\hline DP4 & Male & Married & $\begin{array}{c}\text { Deputy } \\
\text { Principal }\end{array}$ & $\begin{array}{l}\text { High } \\
\text { school }\end{array}$ & $\begin{array}{c}\text { Master's } \\
\text { degree }\end{array}$ & 47 & 5 & Kahramanmaraş \\
\hline DP5 & Male & Married & $\begin{array}{c}\text { Deputy } \\
\text { Principal }\end{array}$ & $\begin{array}{c}\text { Elementary } \\
\text { school }\end{array}$ & $\begin{array}{c}\text { Bachelor's } \\
\text { degree }\end{array}$ & 36 & 4 & Siirt \\
\hline P1 & Male & Married & Principal & $\begin{array}{l}\text { High } \\
\text { school }\end{array}$ & $\begin{array}{c}\text { Bachelor's } \\
\text { degree }\end{array}$ & 39 & 2 & Siirt \\
\hline P2 & Male & Married & Principal & $\begin{array}{c}\text { Middle } \\
\text { school }\end{array}$ & Ph.D. & 37 & 5 & Kahramanmaraş \\
\hline P3 & Male & Single & Principal & $\begin{array}{c}\text { Elementary } \\
\text { school }\end{array}$ & $\begin{array}{c}\text { Bachelor's } \\
\text { degree }\end{array}$ & 33 & 3 & Siirt \\
\hline $\mathrm{P} 4$ & Male & Married & Principal & $\begin{array}{l}\text { Middle } \\
\text { school }\end{array}$ & $\begin{array}{c}\text { Bachelor's } \\
\text { degree }\end{array}$ & 32 & 3 & Kahramanmaraş \\
\hline
\end{tabular}




\begin{tabular}{|l|c|c|c|c|c|c|c|c|}
\hline \hline P5 & Male & Married & Principal & $\begin{array}{c}\text { Elementary } \\
\text { school }\end{array}$ & Ph.D. & 36 & 2 & Kahramanmaraş \\
\hline
\end{tabular}

Note: ${ }^{*}$ Nicknames were assigned to participants (T: Teacher, DP: Deputy Principal, P: Principal)

As viewed in Table 1, one participant was female whereas the rest of them were male, two participants were single whilst the rest of them were married, seven participants were teachers while five participants were deputy principals and five participants were principals, six participants served at elementary schools, six participants served at middle schools, and five participants served at high schools, and lastly, three participants held master's degrees and two participants held Ph.D. whilst the rest of them held bachelor's degrees. The participants had an age range from 30 to 47 years and a duration of service ranging from 2 to 12 years at the school.

\subsection{Data Collection Tool}

The research data were collected by using the semi-structured interview form developed by researchers and comprised of open-ended questions. In the study, the semi-structured interview form was utilized to receive participants' views in a natural setting, obtain detailed information from participants, reveal the underlying reasons behind answers given by participants to interview questions, and direct new questions to participants during the interview. The questions of the semi-structured interview were evaluated by three experts who were faculty members in the field of educational management and had experience in qualitative research. In light of expert opinions, three questions were removed from the interview form whilst four probing questions were added to the interview form. To test whether the semi-structured interview questions were in line with the research aim, a pilot study was performed with a participant from a school in Kahramanmaraş and another participant from a school in Siirt. Considering the expert opinions and the results of the pilot study, six questions were selected for the interview form. The interview questions were as below:

1) What do you think is "social media"? Can you define it?

2) Can you explain whether the use of social media at schools is necessary? Can you also state your justifications on this issue?

3) For what purposes is social media used in your school? Can you explain?

4) Can you express your views about the likely effects of using social media at schools?

5) 5.What do you recommend to ensure that the schools use social media effectively and efficiently?

\subsection{Data Collection}

The research data were collected in the fall semester of the academic year of 2021-2022 and each interview took 35 minutes on average. Participation in the research was on a "voluntary" basis, and before the interview, detailed information about the research aim was given to participants. Besides, it was guaranteed that the participants would be free to withdraw from the research any time they desired and there would be no risk in taking 
part in the research, and accordingly, the participants were asked to sign an informed consent form. Only 12 of 17 research participants agreed that their individual interviews could be audio-recorded. The individual interviews held with the remaining five participants were recorded in written format. Additionally, the participants were asked to fill in the semi-structured interview form to avoid the loss of data in the research. Audio records and participants' remarks in the semi-structured interview form were transcribed in the research upon being coded with participants' nicknames. In this regard, teachers, deputy principals, and principals were coded consecutively with letters of T, DP, and P, and also, a number was assigned to the coding letter of each participant.

\subsection{Data Analysis}

All interviews held during the research were first transcribed via Microsoft Word and then transferred to NVivo 12.0 software without being subject to any data elimination. Texts for all interviews were read line by line (line by line analysis). Open coding was utilized to create categories relevant to the data about the phenomenon that was addressed in the research, axial coding was employed for relating together the categories obtained in the open coding by establishing the ties between these categories, and the selective coding was used for showing the relationship of a previously selected category with other categories (Baş \& Akturan, 2017; Creswell, 2020; Merriam, 2009; Strauss \& Corbin, 1990). The inductive descriptive analysis, content analysis, and the constant comparison technique were utilized in the interpretation of interview texts. Descriptive analysis tries to present participants' views through direct quotations. In content analysis, the data that have similar characteristics are exhibited under the same themes or categories. In the constant comparison technique, the inductively coded data are constantly compared to each other (Ekiz, 2003; Schreier, 2014; Yıldırım \& Şimşek, 2013). In this context, through a holistic approach, the codes obtained in the research were exhibited under the same theme by taking the similarities and differences into consideration. Thus, an inductive method was utilized while the research themes were being created. Also, the statements that were deemed important in interviews were supported with direct quotations and confirmed with codes and themes. It was ensured that the direct quotations would be distinctive, stunning, and illuminating (Neuendorf, 2002; Ünver, Talu Bümen, \& Başbay, 2010).

\subsection{Validity and Reliability}

As validity and reliability are concepts pertaining to quantitative research, the concepts of credibility, transferability, consistency, and confirmability should be used in qualitative research instead of validity and reliability (Houser, 2015; Mills, 2003; Roberts \& Priest, 2006; Shenton, 2004). Credibility refers to internal validity and indicates to what extent the research data reflect the reality, transferability pertains to the generalizability of the data and the external validity, consistency denotes the reliability and replicability of the research, and confirmability points to the objectivity of the research (Lincoln \& Guba, 2013; Yıldırım \& Şimşek, 2013). To promote credibility in the study, the interview 
form was submitted to experts to receive their opinions about interview questions, the relevant literature was reviewed, neutrality was ensured, an audio recorder was used, a pilot study about interview questions was performed, and a part of the research data was supported with direct quotations. To assure transferability of the research, the purposive sampling methods applied in qualitative research were used, the research findings were interpreted together with the findings of other studies in the relevant literature, all stages of the research were presented in detail, and a simple and clear language was utilized in the research. To ensure consistency across the research, more than one researcher got involved with the study, a general consensus about all themes and codes was reached, and the right to withdraw from the study was granted to the participants. To promote confirmability in the study, the research sample included participants with a variety of demographic characteristics, the raw data collected in the research were saved and stored by the researchers, and also, the participants were asked if they agreed with the obtained results after research results were sent to them, and thus, the research results were confirmed by participants.

\section{Findings}

The research findings were presented on the basis of answers given by participants to the questions prepared in light of the research aim.

\subsection{Views about the Definition of Social Media}

Under this theme, the question, "What do you think is social media? Can you define it?", was posed to participants. Figure 1 summarized participants' views about the definition of social media.

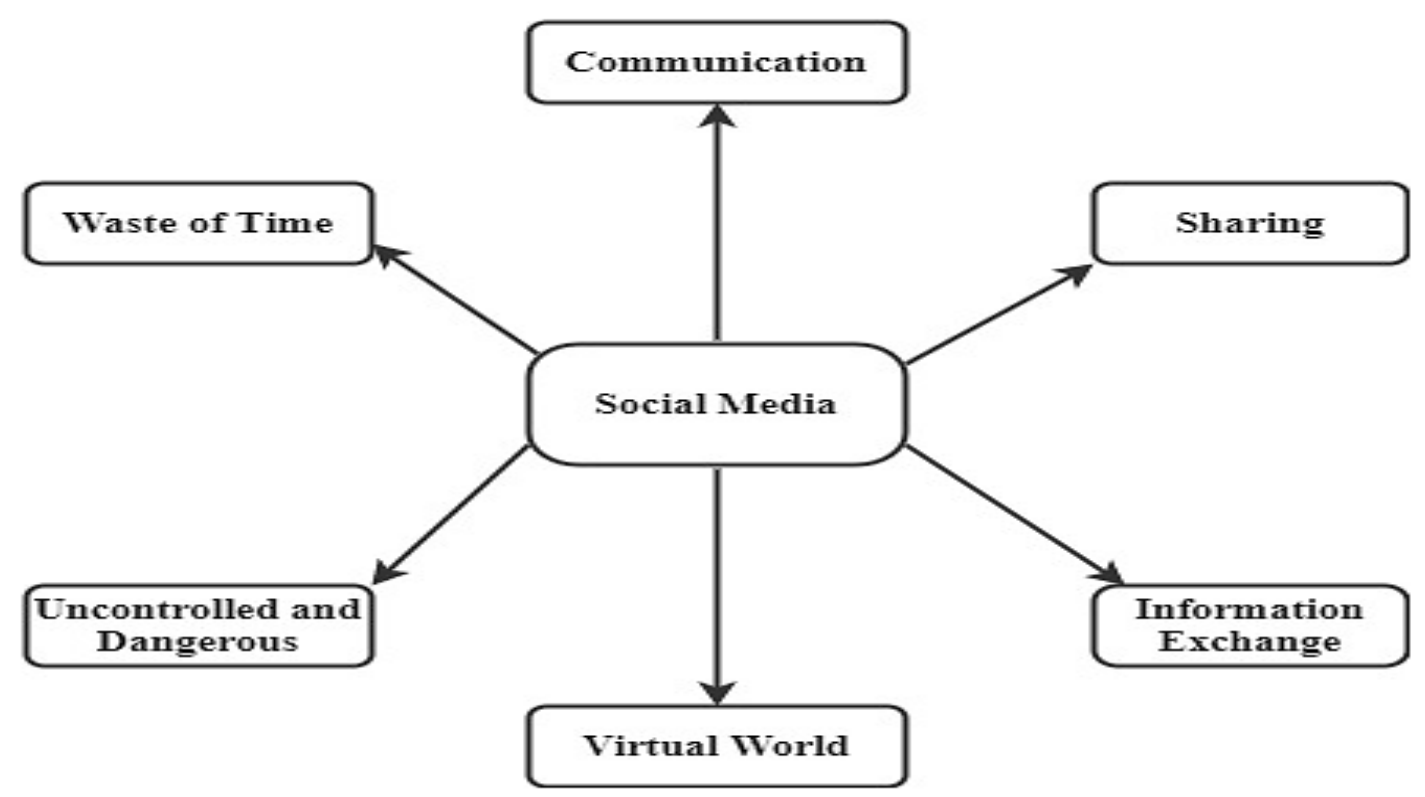

Figure 1: Participants' views about the definition of social media 
As viewed in Figure 1, the participants' views about the definition of social media were evaluated under six sub-themes, namely, "communication", "sharing", "information exchange", "virtual world", "uncontrolled and dangerous", and "waste of time".

Upon the examination of participants' definitions about the concept of social media, it is discerned that a significant part of the participants (T1, T2, T3, T5, DP2, DP3, DP5, and P5) perceived social media as a communication tool. In this respect, social media was defined by T1 as "a tool enabling the communication between human beings", by DP3 as "a tool allowing human beings to communicate with each other by using technological facilities regardless of time and space constraints", by P5 as "a communication tool enabling individuals to interact with other individuals or institutions in today's world where face-to-face interpersonal communication decreased". Likewise, T2, T3, T5, DP2, and DP5 evaluated social media as a tool for interaction and communication.

Next, by emphasizing the "sharing" function of social media, P1 stated that social media could be defined as "any type of internet-based non-face-to-face sharing tool". Moreover, P4 serving as a school principal at a relatively young age, 32 years, underlined the "information exchange" function of social media by saying that the social media resembled a large coffee house/library that had books. Furthermore, T4 and DP1 stated that social media was a virtual world, and any sort of unrealistic events and situations could be experienced in this virtual world. However, T7 underscored the negative side of social media and defined social media as "a dangerous and uncontrolled platform with ambiguous repercussions... A digital arena where human beings could hide their real identities and make fake friends and public recognition could be promoted without needing any help from others...". Besides, other participants attributing negative meanings to the concept of social media, DP4 and P3, said that they viewed social media as a platform that wasted human beings' time and inflicted harm on their social relations. On the other hand, P3's characterization of social media as "a devil's game where human beings most of the time wasted their time...", in other words, P3's depiction of social media as a devil's game, captured attention.

\subsection{Views about Whether the Use of Social Media at Schools is Necessary}

Under this theme, the question, "Can you explain whether the use of social media at schools is necessary? Can you also state your justifications on this issue?", was directed to the participants. Figure 2 summarized the participants' views about whether the use of social media at schools was necessary. 


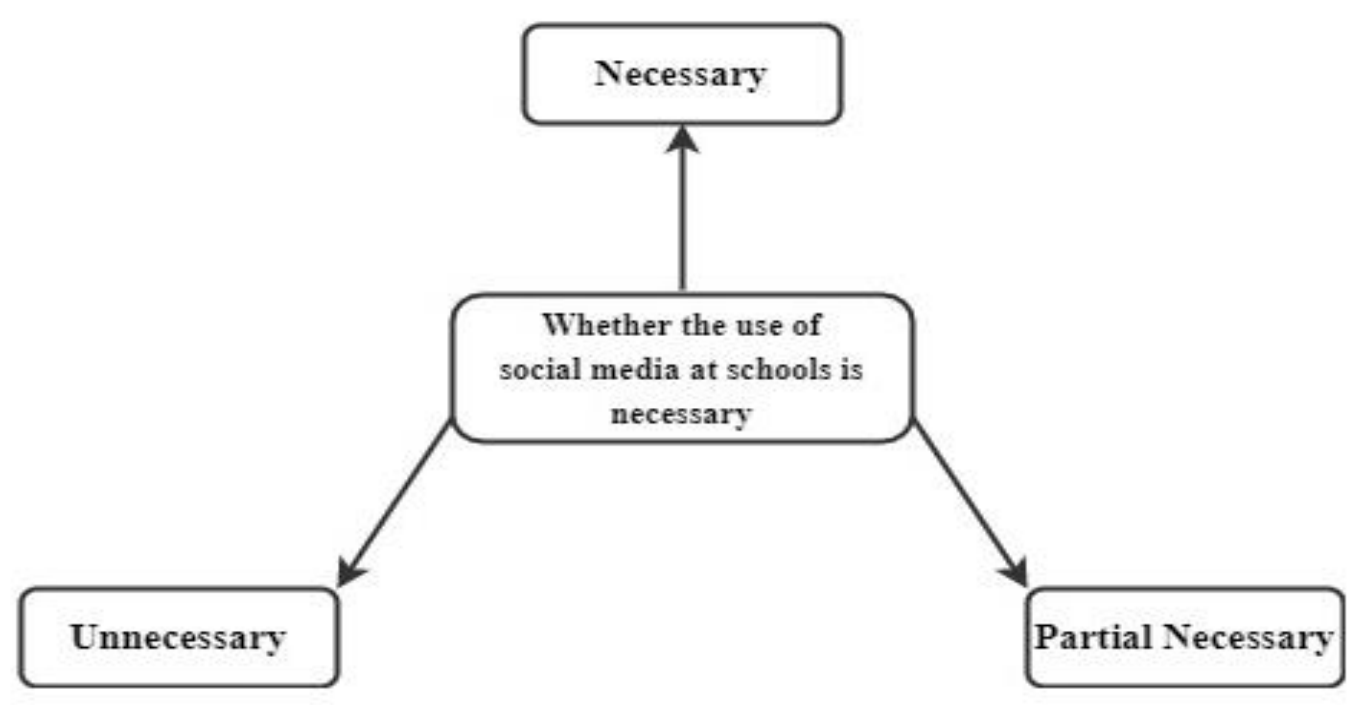

Figure 2: Participants' views about whether the use of social media at schools is necessary

As viewed in Figure 2, participants' views about whether the use of social media at schools was necessary were categorized under three sub-themes, namely, "necessary", "unnecessary", and "partially necessary".

The majority of the participants (T1, T3, T5, T7, DP1, DP2, DP3, P1, and P5) told that the use of social media at schools was necessary and indispensable. In response, the follow-up question, "Why do you think that the use of social media at schools is necessary and indispensable?", was posed to these participants. In this context, T1 said, "The use of social media is essential for schools as well because our age is the information age.", DP1 stated, "The use of social media is crucial in terms of accessibility. Mostly, young individuals and students use social media platforms. Thus, the schools interested in reaching young people and students are obliged to use social media platforms actively.", and DP2 told, "The use of social media is needed to ensure the healthy development of interaction between the school and students' parents/legal guardians.". Moreover, stressing the importance of interaction, stakeholder participation, and adaptation to the environment, P5 who had a Ph.D. and was a principal of an elementary school for two years expressed his reasons for the necessity of using social media at schools as in the following: "The schools are obliged to strengthen the communication with their stakeholders if they aspire to perform their activities effectively. Otherwise, something will always be missing if the schools cannot express themselves to stakeholders, the environment, and the external world. If the communication is not effective, the school will be incapable of demonstrating itself, its efforts, its activities, and so on, and in the end, negative perceptions about the school will proliferate. No matter how accurately and successfully you do your job, if you cannot show it by using communication channels effectively, you will experience challenges and problems in institutional sense (P5)."

Furthermore, T7 who had views similar to those expressed by P5 and held a master's degree stated her reasons for the necessity of using social media at schools by saying that the use of social media at schools was necessary to promote recognition, competition, and awareness and attract good students to the school by telling, "In today's 
world, promoting recognition via social media is very crucial for all sectors. To enhance awareness about themselves and attract more customers, that is to say, students, under the current market conditions, the educational institutions are also in need of the external world."

On the other hand, some participants (T4, T6, DP4, P2, P3, and P4) stated that the use of social media at schools was unnecessary based on reasons suggesting that the social media did more harm than good, hindered socialization, and was used for purposes irrelevant to its real purpose. In this respect, T4 stating, "The use of social media at schools is a superfluous and unnecessary practice that keeps students' minds busy...", DP4 saying that there was no valid ground for the use of social media at schools by saying, "... Unfortunately, students devote most of their time to social media platforms. Just as social media leads to an increase in the number of asocial students, it can also pave the way for problems resulting in violence among students.", and P2 telling, "Without social media, the schools have managed very well to exist up to the present... Tens of times, I personally witnessed that the social media caused students to have social media addiction." pointed out that there was no valid ground for the use of social media at schools. However, T2 and DP5 avoided expressing a clear view about the necessity of using social media at schools. Both said that the use of social media at schools was necessary for certain situations, however, the use of social media could not be considered as a sine qua non for schools. In this sense, DP5 implied that the use of social media at schools was not very necessary due to its likely consequences by telling, "The use of social media at schools is not very necessary... Who should perform this duty, who should assume this responsibility, or does the school have such a responsibility?".

\subsection{Views about the Purpose of Using Social Media at Schools}

Under this theme, the question, "For what purposes is the social media used in your school? Can you explain?", was directed to participants. Figure 3 summarized the participants' views about the purpose of using social media at schools.

As discerned in Figure 3, the participants' views about the purpose of using social media at schools were grouped under four sub-themes, namely, "education \& instruction", "giving information and sharing", "socialization", and "promotion and advertisement".

Of the participants stating that the social media was used for the purpose of education and instruction by way of giving homework and extra assignments to students and sharing students' course-related activities and presentations (T1, T5, DP5, P1, P2, and P4), T5 said, "We frequently make use of social media platforms to ensure that the courses offered via the Educational Informatics Network of Turkey (EBA) due to the pandemic are better comprehended.", whilst DP expressed his view on this topic by telling, "We present the performed activities to students' legal guardians/parents and the school community via social media. To motivate other students, we share particularly the activities carried out during the pandemic. Students' legal guardians/parents become very happy when course activities are shared as examples.". Unlike other participants, P1 put forward that they used social media not 
only for instructional purposes but also to teach values to students and equip them with proper behaviors.

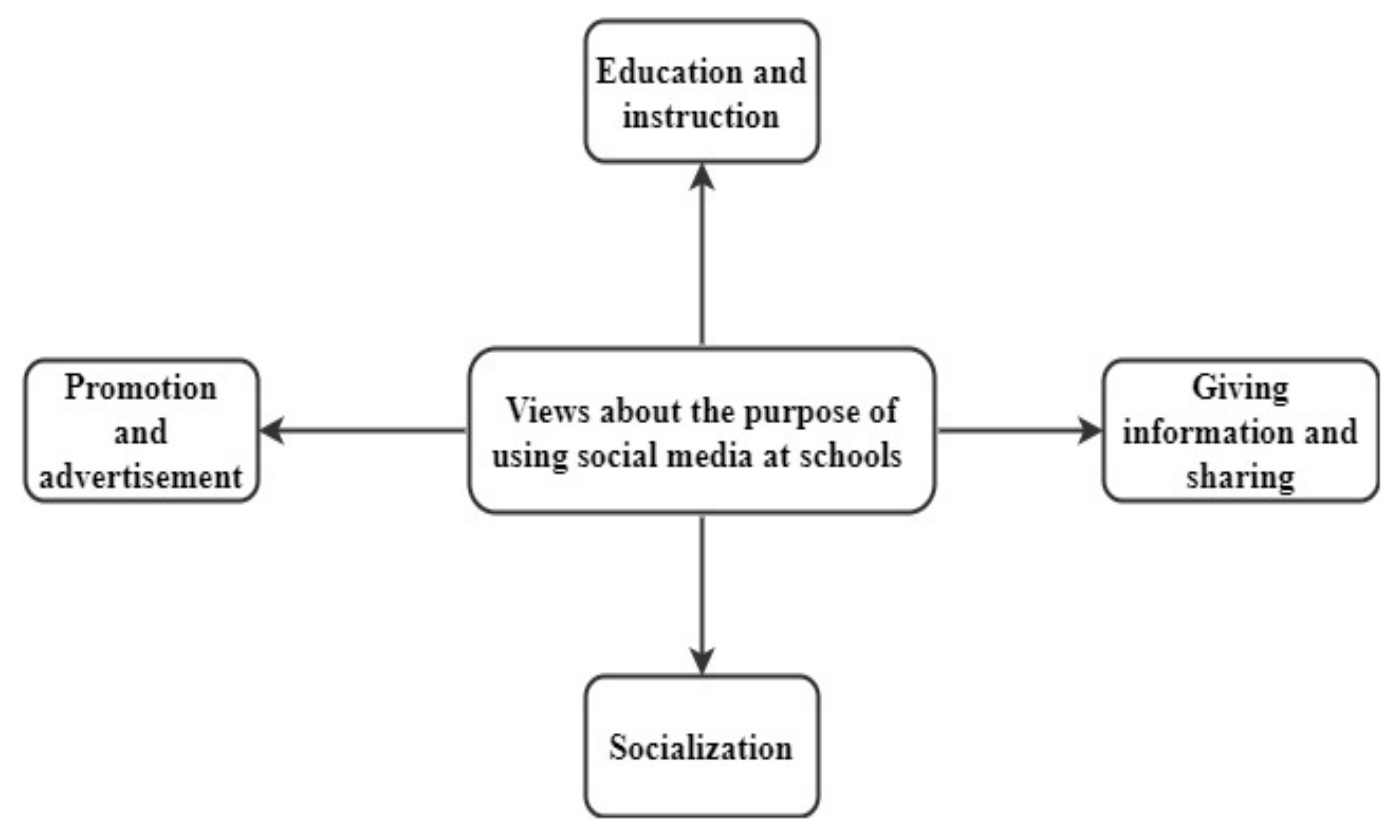

Figure 3: Participants' views about the purpose of using social media at schools

Moreover, the participants saying that giving information and sharing were one of the purposes of using social media at their schools (T2, T3, T6, DP2, P1, and P5) told that they used social media platforms mostly to have interaction with stakeholders, inform students' legal guardians/parents about important announcements and instructions in due time, and have a healthy information exchange between students' legal guardians/parents and the school. On this topic, T3 highlighted that the use of social media was unavoidable for schools by saying, "Currently, almost all information and announcements were conveyed to students' legal guardians/parents by using social media platforms...". Next, DP2 indicated the relationship of the use of social media at schools with the school's accountability, prestige, and image by telling, "I use social media platforms to share school-related announcements and news, exchange information about the school, assure accountability, and promote school's prestige and image.". Like other participants, P1 also stated that they utilized social media to give information about all sorts of meetings, announcements, and important notifications about the school.

Furthermore, T4 and DP1 told that one of the purposes of using social media at their schools was socialization. In this respect, T4 said that social media created the conversation setting at the school and this setting contributed to socialization. Additionally, DP1 underlined that social media made positive contributions in terms of socialization by enabling the communication between students and their legal guardians/parents who did not know each other.

Lastly, in the research, it was found that one of the purposes of using social media at schools was promotion and advertisement. The participants who expressed their views 
about this topic (T7, DP3, DP4, and P3) stated that the social media was used for purposes irrelevant to its real purpose in general and was utilized particularly in an exaggerated manner to find favor in some people's eyes, win the administrator's affection, and be appreciated by students and their legal guardians/parents. In this regard, T7 who held a master's degree and had a service duration of eight years at her school said that social media could serve different purposes at schools by telling, "Almost all school administrators with whom I worked at this school, excluding a few of them, had posted irrelevant, exaggerated, and self-advertising social media content to give the message, 'Hey, look, I am different from others.', and to prove that they were more successful than other administrators.". In contrast to T7's views, P3 suggested that the schools needed promotion and publicity activities just as profit-oriented institutions did today, and so, the social media platforms could be used for promotion and publicity purposes.

\subsection{Views about the Likely Effects of Using Social Media at Schools}

Under this theme, the question, "Can you express your views about the likely effects of the use of social media at schools?", was posed to participants. Figure 4 summarized participants' views about the likely effects of the use of social media at schools.

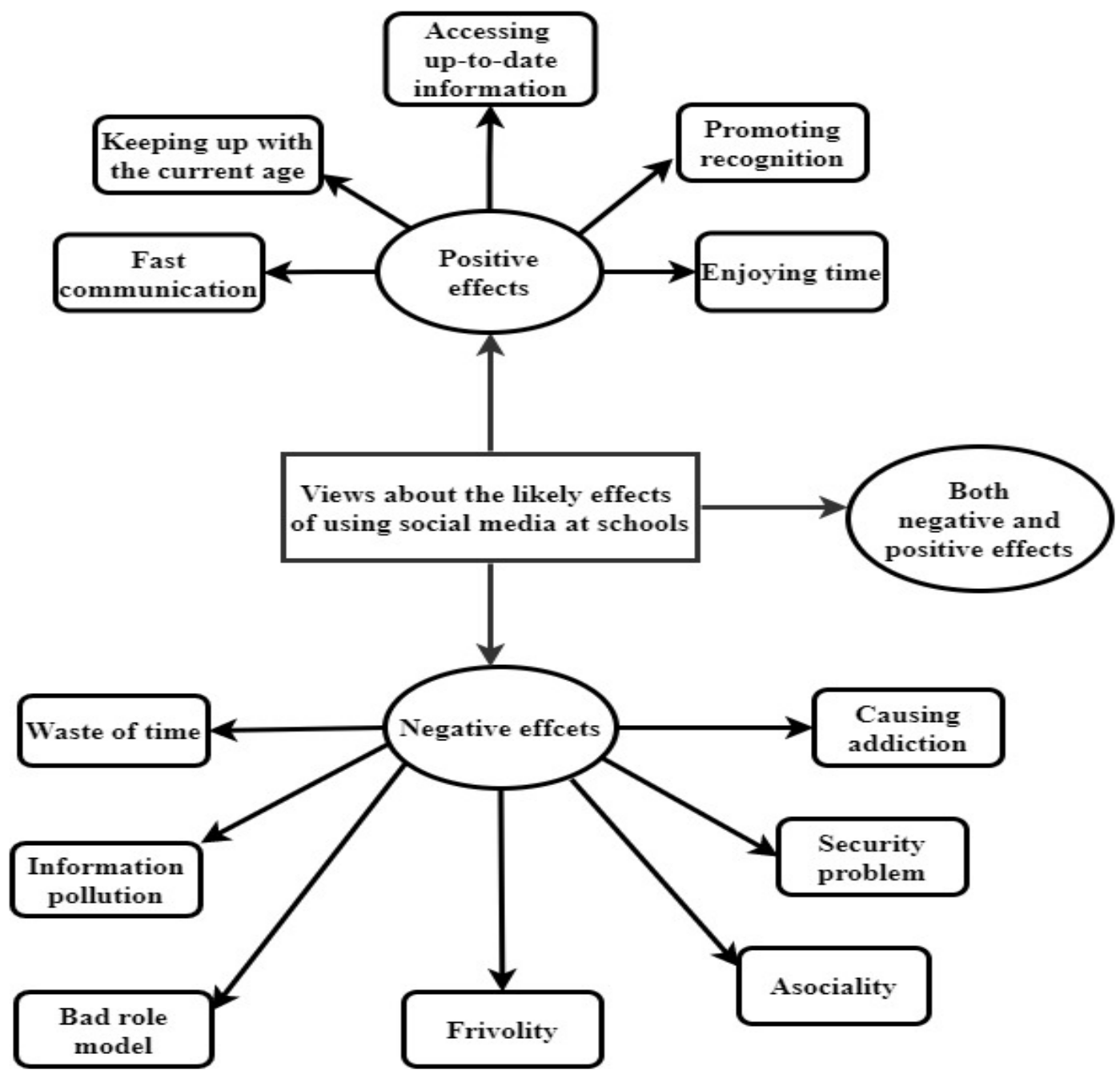

Figure 4: Participants' views about the likely effects of using social media at schools 
As is discerned in Figure 4, the participants' views about the likely effects of using social media at schools were categorized under three sub-themes, namely, "positive effects", "negative effects", and "both negative and positive effects".

First, in the research, the sub-theme, "positive effects", was comprised of the codes, "accessing up-to-date information", "promoting recognition", "enjoying time", "fast communication", and "keeping up with the current age". The participants saying that the use of social media enabled people to access up-to-date information (T1, T3) told that social media was effective in conveying the latest and newest information to students, their legal guardians/parents, and teachers. In this regard, T1 stated his views on this topic by saying, "We can convey the latest and most current information that we want to announce to our counterparts", and T3 told, "As you know, we have to continuously post content about the state of education $\mathcal{E}$ instruction due to the COVID-19 pandemic. We actively use social media in announcing the newest information.". Besides, T7, one of the participants saying that social media promoted school recognition (T7, DP3), told, "The social media promotes the recognition of a school and allows the demonstration of performed works to large masses.". Moreover, emphasizing another function of social media, "enjoying time", DP1 said, "The social media platforms create a setting for conversation between users, and this, in turn, allows the social media users to have a good time. It can be said that social media creates an entertaining environment in our school.". Furthermore, both P1 stating that the social media used by schools enabled fast interaction and communication and P5 telling that social media allowed people to keep up with the current age expressed almost similar views about the effects of social media. In this framework, P1's and P5's views on the topic are as follows: "Thanks to social media, a system of instant and fast interaction was put in place in our school. We can communicate with our students and their legal guardians/parents immediately in a very short period... (P1)." "We know that everyone from A to Z uses social media platforms. In the face of such a situation, we as the school administration have to use social media because today is the age of information and technology... If a system cannot keep up with its age, it cannot survive... (P5)"

Second, in the research, the sub-theme, "negative effects", was comprised of the codes, "causing addiction", "security problem", "asociality", "frivolity", "bad role model", "information pollution", and "waste of time". In other words, the participants expressed views proposing that the overuse of social media platforms at schools caused addiction in students (T4, P4), certain security problems (DP2), asociality along with the interruption of social relations (T6), frivolous and worthless conversations (P2), bad role models (P3), inaccurate information or information pollution (DP5) and waste of time (T5). On this topic, P4 stated, "The students expecting everything from social media develop an addiction to social media platforms after a while. Numerous complaints reach our consultancy services and us on this matter...", DP2 said, "Making social media posts public to everyone and sharing them with people can give rise to serious security problems.", and T6 told, "The socialization can decrease, unnecessary disputes between schools can take place, and social relations between individuals can be damaged.". Besides, P2 pointed out that the social media at schools created an informal environment, and this informal environment, in turn, led 
to frivolity, and P3 put forward that, most of the time, unwanted behaviors and situations were shared via social media platforms and this, in turn, created bad role models for students. Moreover, DP5 stated that the social media platforms brought about problems of accessing accurate information and information pollution as social media platforms were open to the use of all people regardless of whether the topic was relevant to them or not. Lastly, by drawing an analogy between social media and a gnawing rodent, T5 said the following: "I draw an analogy between social media platforms and a 'rodent'. Just as rodents destroy anything they find by gnawing on it, social media platforms also cause time loss by consuming time. Social media is a waste of time not only for students but also for everyone...(T5)"

Third, in the research, the sub-theme, "both negative and positive effects", refers to participants who do not express a clear view or are neutral about the use of social media at schools. From among all participants, only T2 and DP4 expressed views in this direction. T2 shared an evasive view by saying, "The use of social media at schools can have both useful and harmful effects... In my opinion, it is not possible to decide for what and for whom the social media is useful or not.". Likewise, DP4 avoided expressing a clear view about this topic by telling that social media was necessary for communication but could have unpredictable consequences due to certain security problems.

\subsection{Views about Recommending the Use of Social Media at Schools}

Under this theme, the question, "What do you recommend to ensure that the schools use social media effectively and efficiently?", was directed to participants. Figure 5 summarized the participants' views about recommending the use of social media at schools.

As is discerned in Figure 5, the participants' views about recommending the use of social media at schools were grouped under three sub-themes, namely, "measures about societal values", "legal measures", and "technical measures". 


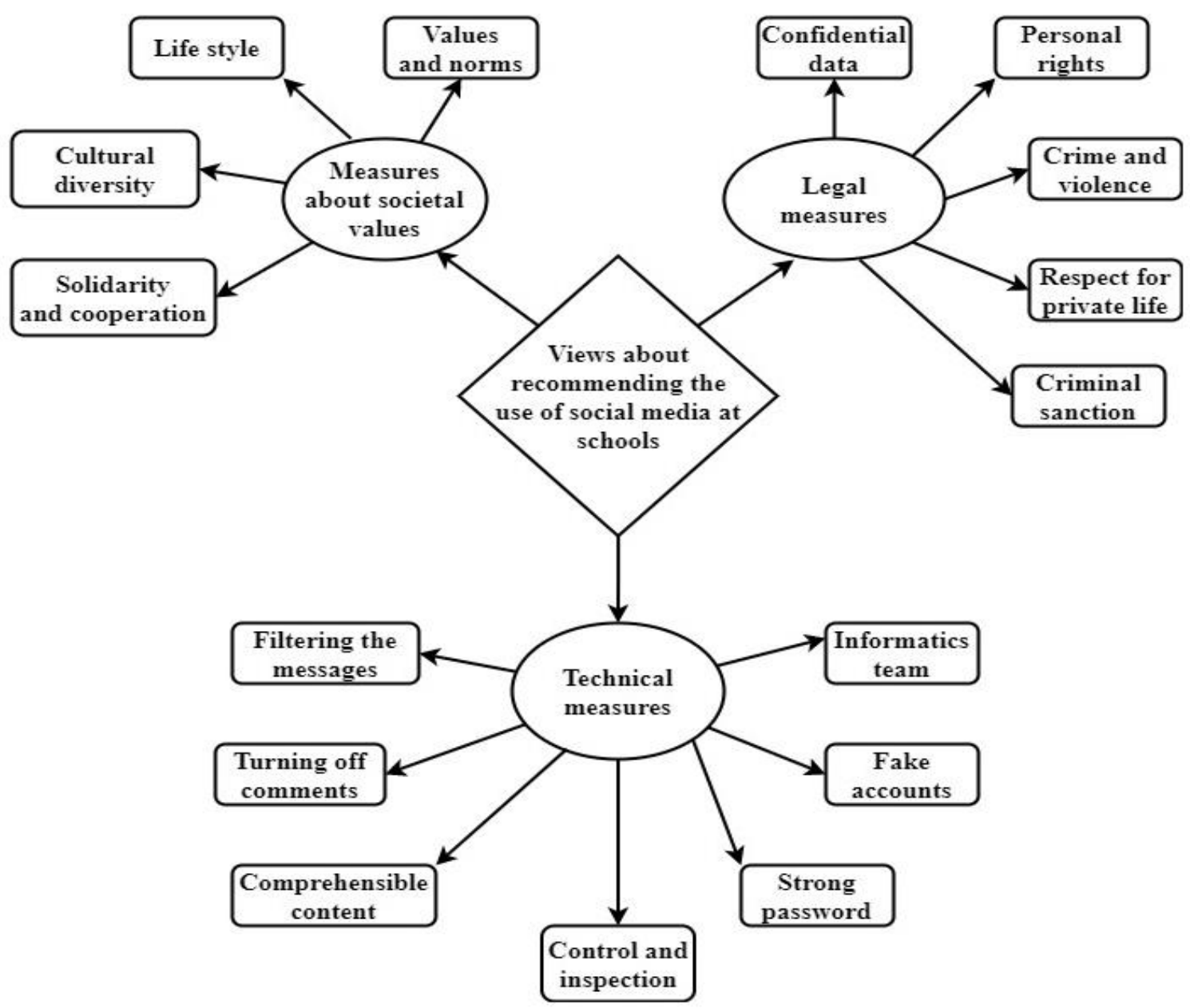

Figure 5: Participants' views about recommending the use of social media at schools

First, in the research, the sub-theme, "measures about societal values", was comprised of the codes, "lifestyle", "values and norms", "cultural diversity", and "solidarity and cooperation". In this context, some participants (T1, T5, DP2, DP3, DP5, and P5) stated that, while posts and information were being shared via social media, the societal sensitivities such as respect for individuals' lifestyles, appropriateness to societal values, norms, and cultural diversity, and promotion of solidarity and cooperation should be taken into consideration to ensure more effective and efficient use of social media at schools. T1 told, "We have students and student parents/legal guardians who have different cultures, customs, and traditions. As a natural consequence, posts that do not contradict with students' and their parents'/legal guardians' customs and traditions should be shared...", whilst P5 said, "On social media platforms, the emphasis should be placed on posts enabling students to integrate with each other and developing the spirit of solidarity and cooperation among students...". Next, emphasizing the cultural and societal differences with which each school was faced, DP5 underlined that, at schools, the social media posts should be in compliance with the principles of respecting cultural diversity and differences. Lastly, DP2 stated that each individual's lifestyle could be different from other individuals' 
lifestyles, and the social media platforms should be used by embracing this difference as a natural situation.

Second, in the research, the sub-theme, "legal measures", was comprised of the codes, "confidential data", "personal rights", "crime and violence", "respect for private life", and "criminal sanction". In this respect, the participants who emphasize that the legal rights should be taken into consideration to make the use of social media functional (T4, T7, DP1, DP3, DP4, P2, and P5) proposed that, on social media, the confidential data about the institution and people should not be disclosed in posts, the personal rights that individuals have as a natural result of being a human being should be respected, the criminal and violent content should not be posted, the right to privacy should be respected, and making declarations likely to be subject to criminal sanctions should be avoided. T7 said, "Posts targeted against the prestige of human beings in society should not be shared via not only the school social media accounts but also our personal accounts... The basic principle should be the following: Do not treat people the way you do not want to be treated.". Moreover, DP1 pointed out that social media posts should avoid promoting crime and punishment and have the qualities to encourage people to become hoped-for good citizens. Furthermore, viewing the case from a more holistic perspective, P2 emphasized that the posts that would not result in criminal sanctions should be shared while social media platforms were being used at schools. Lastly, T4 quoted an incident that he witnessed with respect to the right to privacy while using social media: "The photograph of a female student ranking first in a school-wide contest held in my previous school besides her photographs including her friends while receiving her prize had been shared via the school social media account. The student's parent who saw the posted photographs came to the school administration by expressing great anger... Asking, "How can you post my daughter's photographs without my permission?", the parent was saying that he/she would file a criminal complaint to the office of the public prosecutor. Our school administrators and our friends who posted the photographs were really very demoralized. I guess this situation was exactly a case of impairing something while trying to ameliorate it... Fortunately, in the end, some people intervened, and the problem was solved automatically...(T4)"

Third, in the research, the sub-theme, "technical measures", was comprised of the codes, "informatics team", "fake accounts", "strong password", "control and inspection", "comprehensible content", "turning off comments", and "filtering the messages". In this framework, a large majority of the participants (T1, T2, T3, T6, DP2, DP3, DP4, DP5, P1, P2, P3, and P4) stated that the technical measures had to be taken so that social media could be used in line with its real purpose. The participants thinking that the formation of an informatics team at the school would be useful (T3, T6, and P1) told that the examination of the school social media accounts by people with technical expertise would be possible in this way. T3 said, "Firstly, a school team that is savvy about information technologies, security technologies, and ethical principles should be established. This team should also be responsible for enhancing the awareness of the school staff about the topic of social media. However, it should serve more as an instant intervention team to deal with the technical matters.", whilst P4, one of the participants referring to the topic of fake accounts (DP3 and P4), 
emphasized that the fake accounts should be blocked and also, follower requests from fake accounts should not be approved. Moreover, DP5 and P3 stated that the passwords of school social media accounts should be shared solely with persons responsible for social media accounts and it was important to ensure that the passwords to be created for these social media accounts satisfied the security criteria. Furthermore, T2, T3, DP4, and P2 told that the control and inspection mechanisms should certainly be put in place for the school social media accounts, and if possible, the schools should create a new social media platform for themselves. T2's view about this topic is as follows: "Firstly, the schools can create their own social media applications with the support from informatics teachers. Access restrictions can be imposed on social media accounts. Thus, ill-intentioned correspondence can be precluded...(T2)"

Next, under the sub-theme, "technical measures", there are participants emphasizing that the comprehensible content should be posted via social media and such content should not be in a manner to lead to erroneous evaluations (DP2 and P4) besides participants pointing out to the need to turn off comments on school social media posts (T1 and T2). In this regard, T1 stated, "The social media comments can sometimes be reckless and poor quality. Some messages can lead to erroneous comments... The best way is to turn off comments on the posts shared by the school...". However, in opposition to this view, both T3 and T6 told that filtering the comments and messages would be a more appropriate approach. T6's views about this topic are as follows: "Filtering the messages can provide a solution for eliminating inappropriate and unpleasant comments because the messages and comments on the school social media accounts have to be more exquisite than those on accounts of other institutions. Thus, the message filtering system can be an appropriate solution...(T6)"

\section{Discussion, Conclusion, and Recommendations}

This research aimed to evaluate school administrators' and teachers' views about the use of social media at schools as a new platform for organizational communication. In the research, the propositions about the meaning and nature of the school's use of social media which made a great breakthrough in the demand for interaction, communication, and information were analyzed on the basis of school administrators' and teachers' views.

Along with the entry of the internet into our lives, organizations changed their communication habits and began to have access to more diverse communication channels. To benefit from the advantages of social media, which was one of these channels, the schools as the educational institutions also started to use these technologies and got confronted with its positive and negative effects. According to the results of the current research, the concept of social media was defined by participants mostly as the "communication tool" on the basis of its relationships with the concepts of technology and digital in line with its nature. As mentioned above, social media is the informal communication tool demanded more than formal communication tools. According to the study by Bursalığlu (2005) and the study by Doğan (2017), in an educational 
organization which is a social enterprise and in which interpersonal communication has a particular meaning, informal communication plays a more effective role in terms of structure and ambiance. Based on this finding, it can be said that social media was embraced as a communication tool at schools. In addition to this definition, definitions reflecting the characteristics of social media such as "sharing", "information exchange", "virtual world", "uncontrolled and dangerous", and "waste of time" were also created. In this respect, it is discerned that the definitions produced about social media at schools were created by taking positive and negative characteristics of social media into consideration.

In the current research, when the school administrators and teachers were asked whether the use of social media at schools was necessary, the participants' statements were categorized as necessary, unnecessary, and partially necessary. The study by Olowo, Fashiku, Adebakin, and Ajadi (2020) states that the use of social media by schools was necessary for sharing information and competing in the international arena. Also, in the current research, the participants thinking that the use of social media at schools was necessary emphasized the information and technology age and said that not using social media was a meaningless situation just like turning a deaf ear to novelties, changes, and development. On the other hand, it is discerned that a small number of participants telling that the use of social media at schools was unnecessary focused on the harmful aspects of social media. The fact that the majority of participants who thought that the use of social media at schools was necessary and adopted a positive attitude toward the use of social media at schools held master's degrees in the current research was attentiongrabbing. It is considered that this result was obtained as the participants with master's degrees welcomed technological change and novelties more than than the other participants did.

At schools, social media is used for the purposes of education \& instruction, giving information and sharing, socialization, and promotion and advertisement as per the current research. Based on the findings of the current research, it can be asserted that the participants wanted to create a more sincere environment by reducing the distance from stakeholders with the help of social media. This situation may have stemmed from the fact that the needs and demands of students' legal guardians/parents, who formed a large majority of those following the school social media accounts, were taken into consideration by participants. It can be said that the use of social media by participants for the purpose of sharing information facilitated mutual learning. The study by Davis (2010) identified that the use of social media by teachers created a sort of professional learning community and the teachers shared their ideas and resources with teachers from every corner of the world and sought ways of integrating new technologies into the classroom instruction. According to the study by Bowman (2018), the administrators will provide teachers with the greatest support and serve as role models for them. The results of the research conducted by Olowo et al. (2020) in the Nigerian context indicated that the schools used social media platforms to disseminate information, and social media was viewed as a modern tool likely to facilitate the attainment of the education target 
globally. In the research conducted by Güçlü and Özdoğru (2018) in Eskişehir province of Turkey, the schools used social media to share information and news, develop the school's image, advertise the school, enable the stakeholder participation, promote cooperation, announce the activities, provide education, and enhance awareness. In this context, it is discerned that the findings of the current research are supported by the relevant literature.

In the current research, the likely effects of using social media at schools were divided into three sub-themes, namely, positive effects, negative effects, and both positive and negative effects. Accessing up-to-date information easily, promoting recognition, enabling fast communication, keeping up with the current age, and enjoying the time are the positive effects supporting the use of social media at schools. As the social media that could be used in an interactive, customizable, flexible, and optional manner appealed to the expectations and communication styles of today's generation and individuals growing up with websites and benefiting from technology (Fouts, 2012), the participants of the current research emphasized that the social media could not be neglected even if they referred also to its negative effects. The findings of the current study about the positive effects of the use of social media by schools are in a similar vein to the findings of previous research studies asserting that the schools used social media due to advantages such as forming positive relations with stakeholders, sharing information, and building social capital (Couros \& Jarrett, 2012; Cox \& McLeod, 2013; Heath, Maghrabi, \& Carr, 2015). Additionally, the study by Faizi et al. (2013) referred to an implicit benefit of social media by putting forward that all the above-cited benefits of social media enabled stakeholders to participate in the process of school administration. The situations in which the use of social media by schools was inconvenient due to certain risks inherent in the nature of internet use (Goldfarb, Pregibon, Shrem, \& Zyko, 2011) were mentioned in the current research as the negative effects of using social media at schools. In the current research, causing addiction, producing security problems, leading to asociality, creating frivolous situations, the likelihood of being a bad role model, information pollution, and the waste of time were highlighted as the negative effects creating obstacles to the use of social media at schools. The participants of the current research emphasized particularly the damages inflicted/to be inflicted by the use of social media on their students. The findings of the current research show that the participants experienced crisis situations and had trouble coping with such situations. The research carried out by the School Boards Association (2007) with 1,277 students aged 9-17 years indicated that $20 \%$ of the participants viewed inappropriate content on social media sites in the last three months. Also, the study by Derbyshire (2009) pointed out that social media could impair individuals' abilities to have real conversations, reduce their attention span, encourage instant gratification, and create self-centered personalities. Moreover, the results of other research studies demonstrated that the confidential information could be disclosed while social media was being used at schools (Chang \& Chen, 2014; Yost \& Fan, 2014), and the social media caused educators to lose very long time (Newbury et al., 2014). Stressing the importance of time management to prevent the 
loss of time, the study by Hines, Edmonson, and Moore (2008) recommended time planning for the use of social media during the day. Additionally, the findings of the research by Hines, Edmonson, and Moore (2008) pointed out that attention should be paid to privacy limits and a balance should be attained in a way to strengthen the communication with stakeholders. The study by Cater, Davis, Leger, Machtmes, and Arcemont (2013) considers that this balance could be attained via training on the use of social media.

The relevant literature has a variety of research studies referring to positive and negative sides of using social media at schools just as the current research did. The research study performed by Haşiloğlu, Çalhan, and Ustaoğlu (2020) in Ağrl province of Turkey stated that the communication and information exchange with colleagues and the ease of transferring a note to everyone simultaneously were the positive effects of social media and also, the social media contributed to the creation of a peaceful environment at the school, however, the messages sent constantly by stakeholders, particularly by parents, led to fatigue, and also the ties with stakeholders were weakened because they did not personally pay visits to the school any longer as they considered that being in contact via social media was enough. Likewise, the study by Şahin and Üstüner (2018) evaluates that the use of social media had positive effects in terms of sharing information and finding financial resources whereas it had negative effects such as wasting the time, causing addiction, and creating information pollution.

According to the results of the current research, societal, legal, and technical measures should be taken to alleviate the negative effects of using social media and promote its positive effects. The participants of the current research said that the societal measures to be taken for the use of social media were to promote respect to individuals' lifestyles, to post content appropriate to societal values and norms and in line with cultural diversity, and to share posts to promote solidarity and cooperation. Moreover, the research participants recommended taking legal measures to prevent the disclosure of confidential data, to promote respect paid to personal rights that individuals had as a natural result of being a human being, not to post criminal and violent content, to ensure respect to the right to privacy, and to preclude declarations likely to be subject to criminal sanctions. As a matter of fact, an educator who is not aware that the content posted on social media is open to the public and the posted photographs and texts can be recovered even after they are deleted can leave the school vulnerable to potential negative consequences. Furthermore, in the current research, establishing an informatics team, blocking fake accounts, creating a strong password, establishing control and inspection mechanisms, producing comprehensible content, turning off comments, and using the filtering feature for messages were listed as the technical measures that should be taken by schools. The circular, "The Use of Social Media at Schools", issued by the MNET prohibited the use of photographs taken during the lesson and spare time as well as the content likely to have negative psychological and social effects on individuals. Nevertheless, as per the findings of the current research, it can be alleged that the measures taken by the MNET were deemed inadequate. 
In conclusion, even though the educators expressed different views about the use of social media by schools, they embraced the use of social media in general and actively used it at schools. The schools view social media as a tool to communicate with stakeholders because the urge to demonstrate their institutional identities to stakeholders in the best manner forces schools to communicate also via social media platforms. By means of using social media, the schools can acquire information and share it with all members of the school. Thus, educators can also develop their professional skills. However, as a consequence of the inadequacy of conceptual models and directives about the use of social media at schools, the schools cannot specify their communication needs very well in the social media context, rather, the use of social media at schools is reliant on the knowledge and skills of the person responsible for managing the social media, and this situation, in turn, can raise concerns about confidentiality/security. In the current research, obtaining results similar to those found in studies carried out in different developed and developing country contexts can be evaluated as an indicator showing that the relevant authorities have no policy about the use of social media by schools or have no competence in it.

It is evident that strong policies addressing the potential negative effects of the use of social media by schools and providing educators with guidance and supervision are needed. It is recommended that the MNET organize in-service training courses for administrators and teachers, and in these training courses, administrators and teachers should gain competence in ensuring the use of social media to serve the purposes of the school and contribute to the development of the school. Considering the service provided by the school, its institutional goal, and its target audience, a professional social media strategy should be designated, expectations on the use of social media should be clearly identified, and user guidelines should be created. It is recommended that the shared content be controlled and supervised. Also, offering education on the practical use of social media and social media literacy in master's programs can be useful. The development of time plans to ensure the efficient use of social media by schools can be advocated. It can be considered that the practical studies to be performed to produce solutions to problems that are likely to be experienced in the use of social media at schools will contribute to the relevant literature. According to the report by the Economic Policy Research Foundation of Turkey (TEPAV), human development index values for Kahramanmaraş and Siirt provinces are well below the average for Turkey and are quite low as per income, health, and education indicators. In the context of the findings of the current study, similar studies can be performed in provinces with a higher development level. The use of social media by schools can be examined also from the perspective of other stakeholders, and effective policies can be developed by gathering data about institutional communication.

\subsection{Limitations}

In the study, the use of social media at schools could be analyzed solely on the basis of administrators' and teachers' views, and so other stakeholders' views were not received. 
On the other hand, the in-depth interviews held with administrators and teachers had certain references to other stakeholders. Even if a degree of diversity in terms of provinces, school levels, and participants was in effect in this study, it should be borne in mind that the study covered solely some schools in Siirt and Kahramanmaraş provinces of Turkey, and also, the results obtained from the research may have been under the influence of national, regional, and institutional cultures. Besides, teachers and administrators serving at independent preschool institutions were not included as participants in the study. On the other hand, it is considered that the presence of nursery classes in most schools covered by the study could compensate for the lack of data to be obtained from administrators and teachers serving at independent preschool institutions.

\title{
Acknowledgements
}

The authors thank all participants.

\section{Conflict of Interests Statement}

The author declares no conflicts of interests.

\begin{abstract}
About the Authors
Dr. Emine Doğan obtained her doctoral degree in the field of educational administration. She is working as a form teacher at the Çiğli Primary School in the Dulkadiroğlu district of Kahramanmaraş in Turkey. Her main areas of research include administration, leadership, school management, data-based decision-making and organizational behavior.

Dr. Mehmet Sabir Çevik obtained his doctoral degree in the field of educational administration. He is working as a vice principal at the Yunus Emre Primary School in the Central district of Siirt in Turkey. His main areas of research include administration, leadership, school management and organizational behavior.
\end{abstract}

\section{References}

Aharoney, N. (2011). Twitter use by three political leaders: an exploratory analysis. Online Information Review, 36(4), 587-63.

Akgemci, T., Ada, S. ve Korkmaz, E. V. (2016, April). Örgütsel iletişim aracı olarak sosyal medya kullanımının iş tatmini ve örgütsel bağhılı̆̆a etkisi. International Multidisciplinary Conference (IMUCO), Antalya.

Balcı, A. ve Şahin, F. T. (2016). Sosyal medyanın aile katılımında kullanılabilirliği üzerine bir inceleme. Kastamonu Eğitim Dergisi. 24(5), 2309-2320.

Banuta, D. (2011). Comunicareinterna 2.0. PR Romania. https://www.prromania.ro/articole/comunicare-interna/1019-comunicare-interna-20.html adresinden erişilmiştir. 
Baran, B., Keskin, E., \& Genç, Ş. (2014). Teacher can do a test doing bullying and abuse on Facebook examination of situations according to some variables. Journal of Instructional Technologies E Teacher Education, 3(1), 34-43.

Baş, T., Akturan, U. (2008). NVivo ile nitel veri analizi, örnekleme, analiz, yorum. Ankara: Seçkin Yayıncılık.

Bowman, H. (2018). School administrators' use of social media with stake holders to build social capital. Doctoral Dissertation, The University of Houston-Clear Lake, Houston.

Bursalığlu, Z. (2005). Okul yönetiminde yeni yapı ve davranış. Ankara: Pegem A.

Brabazon, T. (2007). The university of google. Aldershot: Ashgate.

Carr, N. (2007). The benefits of going direct. American School Board Journal, 194(4),58-60.

Carr, N. (2011). Restoring trust. American School, 198(6), 38-39.

Cater, M., Davis, D., Leger, B., Machtmes, K., \& Arcemont, L. (2013). A study of extension professional preferences and perceptions of use fullness and level of comfort with blogs as an informal professional development tool. Journal of Extension, 51(4), 113.

Chang, L., \& Chen, J. V. (2014). Aligning principal and agent's incentives: A principalagent perspective of social networking sites. Expert Systems with Applications, 41, 3091-3104. doi:10.1016/j.eswa.2013.10.040

Creswell, J. W. (2020). Nitel araştırma yöntemleri: beş yaklaşıma göre nitel araştırma ve araştırma deseni (Çev. Edt.: M. Bütün, S. B. Demir). Ankara: Siyasal Kitapevi.

Couros, A., \& Jarrett, K. (2012). Twitter. In S. McLeod \& C. Lehmann (Eds.). What school leaders need to know about digital technologies and social media (pp. 147-152). San Francisco, CA: Jossey-Bass.

Cox, D. D., \& McLeod, S. (2013). Social media strategies for school principals. NASSP Bulletin, 98(1), 5-25. doi:10.1177/0192636513510596.

Cox, D. D., \& McLeod, S. (2014). Social media marketing and communications strategies for schools' superintendents. Journal of Educational Administration, 52, 850-868. doi:10.1108/JEA-11-2012-0117

Çam, E., \& İşbulan, O. (2012). A new addiction for teacher candidates: social networks. Turk Online J Educ Technol, 11(3), 14-19.

Davis, M. R. (2010). Social networking goes to school. Education Week, 3(1), 16, 18, 20, $22-$ 23.

Derbyshire, D. (2009). Social websites harm children's brains: Chilling warning to parents from top neuroscientist. https:/www.dailymail.co.uk/news/article-1153583/Socialwebsites-harm-childrens-brains-Chilling-warning-parents-neuroscientist.html

Dembo, S. (2015). Building bridges: making connections. Principal Leadership, 15(9), 26-28.

Doğan, E. (2017). Okullarda informel iletişimimin kullanılma biçim ve düzeyine yönelik öğretmen görüşleri (Yüksek lisans tezi). Siirt Üniversitesi, Sosyal Bilimler Enstisüsü, Siirt.

Ekici, M. ve Kıyıcı, M. (2012). Sosyal ağların eğitim bağlamında kullanımı. Uşak Üniversitesi Sosyal Bilimler Dergisi. 5, 156-167. 
Ekiz, D. (2003). Eğitimde araştırma yöntem ve metodlarına giriş. Ankara: Anı Yayıncılık.

Faizi, R., Afia, A. El, \& Chiheb, R. (2013). Exploring the potential benefits of using social media in education. International Journal of Engineering, 3(4), 50 - 53.

Fancera, S. F. (2019). School leadership for Professional development: The role of social media and networks. Professional Development in Education, 1-13. doi:10.1080/19415257.2019.1629615.

Feyzioğlu B. (2016). Eğitimde sosyal medyanın kullanılmasına ilişkin okul yöneticileri ve öğretmenlerin görüşleri (Yayımlanmamış yüksek lisans tezi). Kocatepe Üniversitesi, Fen Bilimleri Enstitüsü, Afyonkarahisar.

Fouts, J. (2012). Pros and cons of social media in the classroom. https://campustechnology.com/articles/2012/01/19/pros-and-cons-of-socialmedia-in-the-classroom.aspx

Güçlü, N. ve Özdoğru, M. (2018). Kurumsal bir iletişim aracı olarak okullarda sosyal medya kullanımı. The 13 Th International Congress on Educational Administration, Sivas, Turkey, 10-12 May 2018, s.182-194.

Goldfarb, A., Pregibon, N., Shrem, J., \& Zyko, E. (2011). Informational brief on social networking in education. New York Comprehensive Center. Retrieved from http://www.p12.nysed.gov/technology/internet safety/documents/Informational BriefonSocialNetworkinginEducation.pdf.

Haşiloğlu, M. A.,Çalhan, H. S., \& Ustaoğlu, M. E. (2020). Determining the views of the secondary school science teachers about the use of social media in education. Journal of Science Education and Technology, 29(3), 346-354. https://doi.org/10.1007/s10956-020-09820-0

Heath, D., Maghrabi, R., \& Carr, N. (2015). Implications of information and communication technologies (ICT) for school-home communication. Journal of Information Technology Education: Research, 14, 363-396.

Hines, C., Edmonson, S., \& Moore, G. W. (2008). The impact of technology on high school principals. NASSP Bulletin, 92, 276-291. doi:10.1177/0192636508328593

Houser, J. (2015). Nursing research: reading, using, and creating evidence. (3rd ed.). Burlington: Jones ve Bartlett Learning.

Hootsuite \& We Are Social, (2020). Digital 2020 Global Digital Overwiev. https://wearesocial.com/digital-2020 adresinden erişilmiştir.

Huffman, S. (2013). Benefits and pitfalls: Simple guidelines for the use of social networking tools in K-12 education. Education, 134(2), 154-160.

Karcıoğlu, F., Timuroğlu, M. K., Çınar, O. (2009). Örgütsel iletişim ve iş tatmini ilişkisi, bir uygulama. Yönetim, 20(63), 59-76.

Keeney, A. J. (2019). School social workers' perceptions of ethical dilemmas as sociated with electronic media use in school settings. Children $\mathcal{E}$ Schools, 41(4), 203211.doi:10.1093/cs/cdz019.

Köse, Y. (2018). Yükseköğretimde öğrenme ve öğretme amaçlı sosyal medya kullanımına ilişkin akademik yönetici ve öğretim elemanı görüşleri (Yayımlanmamış yüksek lisans tezi). Aksaray Üniversitesi, Sosyal Bilimler Enstitüsü, Aksaray. 
Kulesza, J., De Hondt, G., \& Nezlek, G. (2011). More technology, less learning? Information Systems Education Journal, 9(7), 4-13.

Langridge, D. (2007). Phenomenological psychology: theory, research and method. Harlow: Pearson.

Larkin, P. (2011). Getting connected. Principal Leadership, 12(1), 22-25.

Lincoln, Y. S., Guba, E. G. (2013). The constructivist credo. California, CA: Left Coast Press. Marshall, C., \& Rossman, G. B. (2014). Designing qualitative research. New York: Sage.

Mazer, J. P, Murphy, R. E, \& Simonds, C. J. (2007). I'll see you on "Facebook": The effects of computer- mediated teacher self-disclosure on student motivation, affective learning, and classroom climate. Communication Education, 56(1). http://dx.doi.org/10.1080/03634520601009710.

Milli Eğitim Bakanlığı (MEB), (2017). Okullarda Sosyal Medyanın Kullanılması. http://mevzuat.meb.gov.tr/dosyalar/1833.pdf adresinden erişilmiştir.

Menteşe, M. (2013). Sosyal medya ortam ve araçlarının eğitimde kullanımına ilişkin okul yöneticilerinin ve öğretmenlerin görüşleri. (Yayımlanmamış yüksek lisans tezi). Hacettepe Üniversitesi, Ankara.

Merriam, S. (2009). Qualitative research: a guide to design and implementation. San Francisco: Jossey-Bass.

Mills, G. E. (2003). Action research a guide for the teacher researcher (2 nd. edition). Boston: Pearson Education.

Morahan-Martin, J., \& Schumacher, P. (2000). Incidents and correlates of pathological internet use among college students. Comput Hum Behav, 16(1), 13-29. https://doi.org/10.1016/S0747-5632(99)00049-7.

National School Boards Association (2007). Creating \& connecting: Research and guidelines on online social and educational networking. http://socialnetworking.procon.org/sourcefiles/CreateandConnect.pdf.

Neuendorf, K. A. (2002). The content analysis, guidebook. California: Sage Publications.

Newbury, E., Humphreys, L., \& Fuess, L. (2014). Over the hurdles: Barriers to social media use in extension offices. Journal of Extension, 52(5), 1-10.

Newland Hill, L., \& White, C. (2000). Public relations practitioners' perception of the World wide web as a communication stool. Public Relations Review, 26(1), 31-51.

North eastern University (An Online Forum For Students In Advanced Organizational Communication), (2006). Advanced Organizational Communication (team blog creates to share and discus side as related to blog concepts discussed in the course). http://cmnu531.blogspot.com/2006/05/final-blog-postings-organizational.html adresinden erişilmiştir.

Olmstead, C. (2013). Using technology to increase parent involvement in schools. Tech Trends, 57(6), 28-37.

Olowo, B. F., Fashiku, C. O., Adebakin, A. B., \& Ajadi, O. T. (2020). Social media: A modern tool to enhance communication skills of the secondary school principals in Ekitistate. International Journal of Education and Development using Information and Communication Technology, 16(2), 97-108. 
Patton, M. Q. (2014). Nitel araştırma ve değerlendirme yöntemleri. (Çev. Edt.: M. Bütün, S. B. Demir). Ankara: Pegem Akademi.

Richardson, W. (2009). Blogs, wikis, podcasts, and other powerful web tools for classrooms. California: Corwin Press.

Robets, P., \& Priest, H. (2006). Reliability and validity in research. Nursing Standart, 20, 41-45.

Schreier, M. (2014). Qualitative contentan alysis. In U. Flick (Ed.). The SAGE hand book of qualitative analysis (pp.170-183). London: Sage.

Selwyn, N. (2007). Web 2.0 applications as alternative environments for informal learning a critical review. http://www.oecd.org/education/ceri/39458556.pdf adresinden erişilmiş.

Shenton, A. K. (2004). Strategies for ensuring trust worthiness in qualitative research projects. Education for Information, 22, 63-75.

Strauss, A., Corbin, J. (1990). Grounded theory research: procedures, can ons and evaluative criteria. Qualitative Sociology, 13(1), 3-21.

Sugimoto, C., Hank, C., Bowman, T., \& Pomerantz, J. (2015). Friend or faculty: Social networking sites, dual relationships, and context collapse in higher education. First Monday, 20(3). https://doi.org/10.5210/fm.v20i3.5387.

Şad, S. N., \& Demir, M. (2019). Investigation of teachers' and students' reasons to interact and not to interact on social media in terms of hidden curriculum. Abant Izzet Baysal University Journal of Faculty of Education, 19(1), 346-360. https://doi.org/ 10.17240/aibuefd.

Şahin, M. (2017). Okulun çevre unsuru olarak sosyal medyaya ilişkin yönetici, öğretmen ve veli görüşleri. (Yayımlanmamış doktora tezi). İnönü Üniversitesi, Eğitim Bilimleri Enstitüsü, Malatya.

Şahin, M. ve Üstüner, M. (2018). Sosyal medyaya ilişkin okul yöneticilerinin görüşleri, İnönü Üniversitesi Ĕ̆itim Fakültesi Dergisi 19(1), 335-355. DOI: 10.17679/inuefd.334250

Taşöz-Düşündere, A. (2020). 81 ilde insani gelişme endeksi ve türkiye'nin 2020 küresel performansı. Türkiye Ekonomi Politikaları Araştırma Vakfı. https://www.tepav.org.tr/upload/mce/2020/notlar/81 ilde insani gelisme endek si ve turkiyenin 2020 kuresel performansi.pdf adresinden erişilmiştir.

Tayfun, R. (2010). Etkili iletişim ve beden dili. Ankara: Nobel Yayın Dağıtım.

Tosun, N. B. (2003). Kurumsal iletişim sürecinde reklamın ve imaj yönetiminin bütünleşik konumu. Marmara Üniversitesi İ.I. B.F Dergisi, 18(1), 173-191.

Türkiye İstatistik Kurumu (TÜİK) (2019). Hanehalkı bilişim teknolojileri (BT) kullanım araştırması. $\quad$ https://data.tuik.gov.tr/Bulten/Index?p=Hanehalki-BilisimTeknolojileri-(BT)-Kullanim-Arastirmasi-2019-30574 adresinden erişilmiştir.

Uyanık-Aktulun, Ö. ve Elmas, R. (2019). 21. yüzyıl okul öncesi öğretmenleri için sosyal medya araçları: Muhtemel faydalar. Temel Eğitim Dergisi, 1(4), 6-20. 
Ünver, G., Talu Bümen, N., Başbay, M. (2010). Ortaöğretim alan öğretmenliği tezsiz yüksek lisans derslerine öğretim elemanı bakışı: Ege Üniversitesi örneği. Eğitim ve Bilim Dergisi, 155(35), 63-77.

Yıldırım, A., Şimşek, H. (2013). Sosyal bilimlerde nitel araştırma yöntemleri. Ankara: Seçkin Yayıncilik.

Yildız Durak, H. (2019). Modeling of relations between K-12 teachers' TPACK levels and their technology integration self-efficacy, technology literacy levels, attitudes toward technology and usage objectives of social net works. Interact Learn Environ. https://doi.org/10.1080/10494820.2019.1619591.

Yost, H., \& Fan, S. (2014). Social media technologies for collaboration and communication: Perceptions of childcare professionals and families. Australasian Journal of Early Childhood, 39(2), 36-41.

Young, S., Berube, W., \& Perry, S. (2008). The influence of technology on communication for school leaders: preferences, beliefs, and use. Planning and Changing Journal, 39(1/2), 81-97. 
Author(s) will retain the copyright of their published articles agreeing that a Creative Commons Attribution 4.0 International License (CC BY 4.0) terms will be applied to their work. Under the terms of this license, no permission is required from the author(s) or publisher for members of the community to copy, distribute, transmit or adapt the article content, providing a proper, prominent and unambiguous attribution to the authors in a manner that makes clear that the materials are being reused under permission of a Creative Commons License. Views, opinions and conclusions expressed in this research article are views, opinions and conclusions of the author(s). Open Access Publishing Group and European Journal of Education Studies shall not be responsible or answerable for any loss, damage or liability caused in relation to/arising out of conflicts of interest, copyright violations and inappropriate or inaccurate use of any kind content related or integrated into the research work. All the published works are meeting the Open Access Publishing requirements and can be freely accessed, shared, modified, distributed and used in educational, commercial and non-commercial purposes under a Creative Commons Attribution 4.0 International License (CC BY 4.0). 